\title{
NOTES ON STOMATOPOD CRUSTACEA FROM SERIBU ISLANDS AND ADJACENT WATERS WITH A DESCRIPTION OF A NEW SPECIES ${ }^{1)}$
}

\author{
by \\ M. KASIM MoOSA ${ }^{2}$ ) \\ (Manuscript received 1 June, 1974)
}

ABSTRACT

The stomatopod fauna of Seribu Islands, Jakarta Bay, and adjacent waters is still poorly known. This study reveals the existence of 30 species in this area. A new species belonging to Oratosquilla is described. Records of distribution for those species are based on the material collected from this area only.

IKHTISAR

Fauna stomatopoda Pulau Seribu, Teluk Jakarta, dan perairan sekitarnya masih sangat sedikit diketahui. Tiga puluh jenis, termasuk satu jenis baru marga Oratosquilla, dibicarakan dalam karangan ini. Catatan daerah sebaran untuk jenis-jenis tersebut hanya didasarkan pada material yang dikumpulkan dari daerah ini.

\section{INTRODUCTION}

The stomatopod fauna of Seribu Islands, Jakarta Bay, and adjacent waters is still poorly known. However, some species have been described by some workers, viz., DE MAN (1887) described Protosquilla brooksii (now Chorisquilla brooksii) which was collected from Edam Island, Jakarta Bay; HoLTHUIS's type of Gonodactylus lenzi (now Haptosquilla lenzi) was collected from Jakarta Bay; SUNIER's (1918) material for his publication on the stomatopod collection of the "Visscherij Station at Batavia" (now Lembaga Oseanologi Nasional) was partly collected from Jakarta Bay. Unfortunately these particular specimens are no

1) Contribution of the Lembaga Oseanologi Nasional, Lembaga Ilmu Pengetahuan Indonesia.

2) Lembaga Oseanologi Nasional, Jakarta, Indonesia. 
longer in existence. The present study is based mainly on the existing collection of the Lembaga Oseanologi Nasional (LON = National Institute of Oceanology), with additional specimens from the Institute of Sea Fisheries Research, Jakarta, and the Bogor Zoological Museum, National Biological Institute, Indonesian Institute of Sciences. A total of 30 species of 14 genera belonging to 3 families have been recorded from the area, among those, a new species of Oratosquilla is described.

\section{METHODS}

Measurements of the specimens are given in millimeters $(\mathrm{mm})$. The total length (TL) is measured from tip of rostrum to posterior end of telson along the midline. The carapace length (NL) is also measured along the midline, excluding the rostrum. The count of teeth of the raptorial dactylus always includes the terminal tooth. The Corneal Index (CI) is calculated as carapace length/cornea width x 100 (MANNING 1966).

The records of distribution for the species discussed in this paper are based on the material collected from Seribu Islands and adjacent waters only. The so-called adjacent waters include the offshore waters of the eastern part of South Sumatera, northern part of Sunda Strait, islands situated at southern part of Bangka, and Jawa Sea north of West Jawa. These waters are very close to Seribu Islands and therefore the stomatopod fauna in these waters may have similar composition.

The synonymies herein used are restricted to KEMP (1913), SUNIER (1918), HANSEN (1929), Holthuis (1941) and MANNING \& SERENE (1968). Additional papers will be referred whenever available and necessary.

\section{TAXONOMIC ACCOUNT}

The species so far known from Seribu Islands and adjacent waters are presented in the following list.

1. Chorisquilla brooksii (DE MAN 1887)

2. Gonodactylus chiragra (FABRICIUS 1781)

* 3. Gonodactylus demanii HENDERSON 1893

4. Gonodactylus falcatus (FORSKAL 1775)

5. Gonodactylus platysoma WOOD-MASON 1895

6. Gonodactylus smithii POCOCK 1893 
7. Haptosquilla glyptocerca (WOOD-MASON 1875)

8. Haptosquilla lenzi (HOLTHUIS 1941)

* 9. Odontodactylus cultrifer (WHITE 1850)

10. Pseudosquilla ciliata (FABRICIUS 1787)

11. Pseudosquilla oculata (BRULLE 1836)

12. Acanthosquilla derijardi MANNING 1969

13. Lysiosquilla maculata (FABRICIUS 1793)

14. Alima hyalina LEACH 1817

15. Anchisquilla fasciata (DE MAN 1844)

16. Carinosquilla lirata (KEMP \& CHOPRA 1921)

* 17. Carinosquilla multicarinata (WHITE 1847)

18. Clorida latreillei EYDOUX \& SOULEYET 1841

19. Cloridopsis scorpio (LATREILLE 1825)

20. Harpiosquilla harpax (DE HAAN 1844)

21. Harpiosquilla raphidea (FABRICIUS 1798)

* 22. Oratosquilla gonypetes (KEMP 1911)

* 23. Oratosquilla holochista (KEMP 1911)

24. Oratosquilla inornata (TATE 1883)

25. Oratosquilla interrupta (KEMP 1911)

26. Oratosquilla jakartensis new species

27. Oratosquilla nepa (LATREILLE 1825)

28. Oratosquilla quinquedentata (BROOKS 1886)

29. Oratosquilla tweediei MANNING 1971

*30. Oratosquilla woodmasoni (KEMP 1911)

*) Not represented in the collection.

\section{GONODACTYLIDAE GIESBRECHT 1910}

\section{Chorisquilla brooksii (DE MAN 1887)}

Protosquilla brooksii De MAN 1887: 579, pi. 22, fig. 8. — MANNING \& SERENe 1968: 114 (listed).

Gonodactylus brooksii KeMP 1913: 189-190. HolTHUIS 1941: 290-292.

Chorisquilla brooksii MANNING 1969 a: 159 (in key). — MoosA 1973: 4.

Material. - 1 o $^{\top} 26.98 \mathrm{~mm}$; Sebaru Besar Isl.; coral and sand; coll. M. K. Moosa, 6/4/1968; cat. no. S. 353. - 1 우 27.24 mm; between Burung Isl. and Tikus Isl.; coll. Kasijan R., 27/8/1972; cat. no. S. 872.

Type locality. - Edam Island, Jakarta Bay.

Previous record. - Known only from Edam Island (DE MAN 1887). 


\section{Gonodactylus chiragra (FABRICIUS 1781)}

Squilla chiragra FABRICIUS 1781: 515.

Gonodactylus chiragra KEMP 1913: 155 -162, pi. 9, fig. 107. Sunier 1918: 13-14. - HANSEN 1926: 24-26. - Holthuis 1941: 277-281. MANNING \& SERENE 1968: 114 (listed). - Moosa 1973: 7 - 8 .

Material. - 1 우 44.26 mm; Sakit Isl.; coll. Kasijan R., 28/10/1964; cat. no. S. 303. - 1 q $76.62 \mathrm{~mm}$; data as above; coll. Sapri D., 8/12/1963; cat. no. S. 308. - 1 त 40.18 mm; Pemagaran Isl.; coll. Kasijan R., 28/3/1962; cat. no. S.309. — 2 정 26.80-37.22 mm, 2 우 우 18.10-25.04 mm; Jakarta Bay; cat. no. S. 340-343. - 3 त त 35.18-38.16 mm; west coast of Sebaru Besar Island; coral boulder; coll. Sapri D., 7/4/1968; cat. no. S. 347-349. — 2 ก đ 31.58-35.50 mm; Lancang Kecil Isl.; coll. M.K. Moosa, 7/3/1970; cat. no. S. 351-352. 1 a 36.68 mm, 1936.02 $\mathrm{mm}$; data as above; cat. no. S. $354-355$. - $2<0$ s $26.48-35.68 \mathrm{~mm}$, 1 ㅇ $34.22 \mathrm{~mm}$, and 1 juvenile; data as above; cat. no. S. 358-363. - 4 o $924.70-43.48 \mathrm{~mm}$; Untung Jawa Isl.; coll. M. K. Moosa, 31/12/1963; cat. no. S. 368-371. - 2 त त 35.86-39.46 mm; Sebaru Besar Isl.; dead coral; coll. M.K. Moosa, 6/4/1968; cat. no. S. 372 - 373. - 1 đ $24.56 \mathrm{~mm}, 1$ + $33.12 \mathrm{~mm}$; Petundang Isl.; coll. Kasijan R., 8/8/1961; cat. no. S. 374-375. - 1 † 33.42 mm; Ayer Isl.; dead coral; coll. Subagjo S., 3/3/1971; cat. no. S. 377 . -6 के के $16.66-34.24 \mathrm{~mm}$, 6 우 ㅇ 13.24-38.24 mm; Ayer Isl.; coll. M.K. Moosa, 27/5/1971; cat.

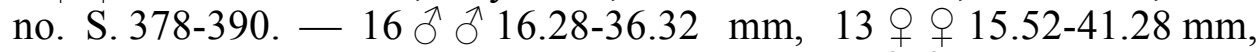
1 juvenile; data as above; cat. no. S. $423-452$. - 2 ㅇ $q 17.20-18.58 \mathrm{~mm}$; data as above; cat. no. S. $456-457$. - 1 o $23.58 \mathrm{~mm}, 1$ ๆ $22.84 \mathrm{~mm}$; Ayer Isl.; coll. Kasijan R., 24/12/1971; cat. no. S. 610-611. - 2 ठे ठ 30.68-92.04 mm, 4 ㅇ 18.46-89.02 mm; between Burung Isl. and Tikus Isl.; coll. Kasijan R., 27/8/1972; cat. no. S. 878-883. - 5 o ${ }^{\lambda}$ 16.72-45.44 mm, 7 o $q$ 30.50-71.22 mm; Kongsi Is1.; sand flat; coll. M.K. Moosa, 28/6/1973; cat. no. S. 1183-1192.

Previous records. - This species is the most common among the coral reefs inhabiting stomatopods in the area. It has been recorded from Damar Kecil Isl. (Alkmaarr Isl.), Jaga Utara Isl. (Noordwachter Isl.), Nyamuk Kecil. Isl. (Enkhuisen Isl.), and from various localities around Seribu Isl. (SUNIER 1918; HolthuIS 1941).

\section{Gonodactylus demanii HENDERSON 1893}

Gonodactylus demanii HeNDERSON 1893: 455, pi. 11, figs. 23, 24. Kemp 1913: 164 -165, pi. 9, figs. 108 - 111. - Holthuis 1941: 282 - 284, fig. 8. MANNING \& SERENE 1968: 114 (listed). 
Remarks. - This species is not represented in the collection and known only from Edam Island (DE MAN 1887 as Gonodactylus n. sp.).

\section{Gonodactylus falcatus (FORSKAL 1775)}

Gonodactylus graphurus DE MAN 1887: 573.

Gonodactylus glabrous KEMP 1913: 167-169, pi. 9, fig. 113.

Gonodactylus falcatus Holthuis 1941: 284 - 288, fig. 9 a. — MANNING \& SERENE 1968: 114 (listed). - Moosa 1973: 8.

Material. - 1 \& $37.58 \mathrm{~mm}$ with a gastropod attached; Untung Jawa Isl; under coral boulder; coll. M.K. Moosa, 31/12/1963; cat. no. S. 082. 1 o $13.74 \mathrm{~mm}$; Sebaru Besar Isl.; under coral boulder; coll. M.K. Moosa, 7/4/1968; cat. no. S. 083. - Is 30.22 mm; Lancang Kecil Isl.; dead coral; coll. M. K. Moosa, 7/3/1970; cat. no. S. 084. - 2 ㅇ 954.52 55.28 mm; Dualsl.; under coral boulder; coll. Sapri D., 27/11/1965; cat. no. S. 095-096. - 2 ○े 16.30-21.88 mm, 1 क $40.48 \mathrm{~mm}$; Ayer Isl.; coral boulder; coll. M.K. Moosa, 29/7/1971; cat. no. S. 453 - 455. 2 우 29.92-38.34 mm; Sakit Isl.; coll. M.K. Moosa, 8/12|/1963; cat. no. S. 557-558. - 1 त $32.22 \mathrm{~mm}, 1+38.36 \mathrm{~mm}$ with 2 gastropods attached; Ayer Isl.; coll. M.K. Moosa, 30/8/1971; cat. no. S. 570 - 571. - 1 $21.50 \mathrm{~mm}$; Rawa Saban fishmarket; coll. Sudarmo, 26/8/1971; cat. no. S. $607 .-1$ त $31.94 \mathrm{~mm}$ with 2 gastropods attached, 1 † 37.90 mm; Ayer Isl.; corals; coll. M.K. Moosa, 27/11/1971; cat. no. S. 614615. - 1 त $29.04 \mathrm{~mm}, 1$ o 36.72 mm; between Burung Isl. and Tikus Isl.; coll. Kasyan R., 27/8/1972; cat. no. S. 876 - 877.

Remarks. - Three of the specimens have gastropod molluscs attached on their ventral surfaces. Boediman (pers. comm.) has identified the gastropods as Caledoniella montrouzieri SOWERBIE 1869. ROSEWATER (1969, as mentioned by MANNING 1969 C) observed that the larger female of this gastropod attached to Gonodactylus from Madagascar on the posterior ventral surface, while the smaller male attached on the anterior part. HOLTHUIS (1941) mentioned the presence of gastropod attached on the ventral surface of Gonodactylus chiragra from Indonesia with sacs of eggs of different stages of development. The specimens from Seribu Island show that the larger gastropods with sacs of eggs are always on the posterior part of the stomatopod. The eggs sacs contain eggs with different stages of development.

Previous records. - Edam Isl. (DE MAN 1887, as Gonodactylus graphurus), Jakarta Bay (HoLTHUIS 1941). 
Gonodactylus platysoma WOOD-MASON 1895

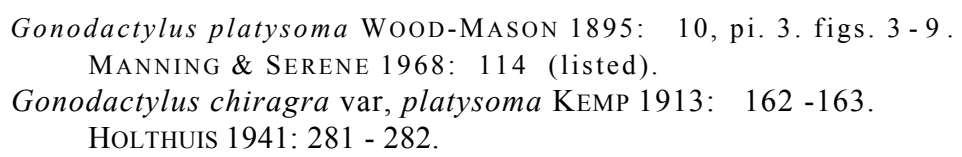

Material. - 1 ๙ 85.82 mm; Ayer Isl.; corals; coll. M.K. Moosa, 26/5/ 1971; cat. no. S. 376. - 1 त $80.20 \mathrm{~mm}$; data as above; coll. Burhanuddin, 1/12/1971; cat. no. S. 606.

Previous record. - None. A new record for the area.

\section{Gonodactylus smithii POCOCK 1893}

Gonodactylus smithii PocOCK 1893: 475 - 476, pi. 20, fig. 1.

MANNING \& SERENE 1968: 114 (listed). - MoOsA 1973: 9.

Gonodactylus acutirostris KEMP 1913: 163 -164.

Material. - 1 + 22.70 mm; Dua Isl.; under coral boulder; coll. M.K. Moosa, 28/11/1968; cat. no. S. 079. - 1 ๆ 22.78 mm; Sakit Isl.; coral boulder; coll. M.K. Moosa, 23/11/1963; cat. no. S. 080. - 1 ○े 30.84 mm; Panjang Isl., Sunda Strait; coll. Kasijan R., 16/3/1963; cat. no. S. 089. - 1 juvenile; Ayer Isl.; corals; coll. M.K. Moosa, 25/5/1971; cat. no. S. 391. - $1438.18 \mathrm{~mm}$; data as above; coll. M.K. Moosa, 30/11/1971; cat. no. S. 612 . - 1 त $31.18 \mathrm{~mm}, 2$ o o $37.14-47.36 \mathrm{~mm}$; between Burung Isl. and Tikus Isl.; coll. Kasijan R., 27/8/1972; cat. no. S. $873-875$.

Previous record. - None. A new record for the area.

\section{Haptosquilla glyptocerca (WOOD-MASON 1875)}

Gonodactylus glyptocercus Wood-Mason 1875: 32. - KeMP 1913: $186-187$. HANSEN 1926: 36. - HolTHUIS 1941: 289 - 290.

Protosquilla cerebralis DE MAN 1887: 575.

Protosquilla glyptocerca MANNING \& SERENE 1968: 114 (listed).

Haptosquilla glyptocercus MANNING 1969 a: 161 (in key). Haptosquilla glyptocerca Moosa 1973: 9-10.

Material. - $3 q$ + 28.02-31.38 mm; south coast of Sebaru Besar Isl.; under coral boulder; coll. M. K. Moosa, 6/4/1968; cat. no. S. 057 - 059. - 1 + $18.14 \mathrm{~mm}$; south coast of Petundang Isl.; coll. Kasijan R., 8/8/1961; cat. no. S. 076. - $2 q \uparrow 26.68-30.12 \mathrm{~mm}$; south coast of Sebaru 
Besar Isl.; coll. M. K. Moosa, 6/4/1968; cat. no. S. 077 - 078. - 1 ð 27.58 mm, 3 ㅇ $924.06-24.60 \mathrm{~mm}$; data as above; cat. no. S. $090-093 .-13$ ๙ 14.18-27.34 mm, 17 ㅇ ㅇ 13.76-31.38 mm; Ayer Isl.; corals; coll. M.K. Moosa, 28/5/1971; cat. no. S. 392-422. - 1 क $30.18 \mathrm{~mm}$; data as above; coll. Sapri D., 5/10/1970; cat. no. S. 572. - 10 ते तै $13.52-25.86 \mathrm{~mm}, 15$ 우 우 18.12-30.68 mm; data as above; coll. M.K. Moosa, 2/12/1971; cat. no. S. 616 - 640. - 1 त $30.82 \mathrm{~mm}, 3$ ㅇ ㅇ 30.98 - $34.96 \mathrm{~mm}$; Kongsi Isl.; sand flat; coll. Sujoto, 29/7/1973; cat. no. S. 1179-1182.

Previous record. - Edam Island, Jakarta Bay (DE MAN 1887).

\section{Haptosquilla lenzi (HOLTHUIS 1941)}

Gonodactylus glaber KeMP 1913: 184, pi. 10, fig. 121. - SERENE 1947: 385-387, pi. 2 , fig. 1.

Gonodactylus lenzi HolthUIS 1941: 288-289. Protosquilla lenzi MANNING \& SERENE 1968: 115 (listed). - TIRMIZI \& MANNING 1968: 19-20, fig. 6.

Haptosquilla lenzi MANNING 1969 a: 161 (in key).

Material. - 1 ก $15.86 \mathrm{~mm}$; Ayer Isl.; corals; coll. M. K. Moosa, 27/5/1971; cat. no. S. 458. - 1 ㅇ $29.08 \mathrm{~mm}$; data as above; coll. M. K. Moosa, 2/12/1971; cat. no. S. 613. - 1 + 23.52 mm; Kongsi Isl.; sand flat; coll. Sujoto, 29/7/1973; cat. no. S. 1193.

Remarks. - The specimens fully agree in most characters with the descriptions of KEMP (1913), SERENE (1947) and TIRMIZI \& MANNING (1968). The fifth abdominal somite furrowed on both sides and posterior half of median portion pitted dorsally.

Type locality. - Jakarta Bay.

Previous record. - Jakarta Bay (HoLTHUIS 1941).

Odontodactylus cultrifer (WHITE 1850)

Odontodactylus cultrifer KEMP 1913: 137-138. — SUNIER 1918: 11-13. — MANNING 1967: 18-22, fig. 5. - Moosa 1973: 13.

Remarks. - The species is not represented in the collection, and known only from east of Seribu Islands (SUNIER 1918). 


\section{Pseudosquilla ciliata (FABRICIUS 1787)}

Squilla ciliata FABRICIUS 1787: 333.

Pseudosquilla ciliata KeMP 1913: 102-103. - SUNIER 1918: 11. - HANSEN 1926: 17 -18. — Holthuis 1941: 261 - 262. — MANning \& Serene 1968: 115 (listed). — Moosa 1973: 13.

Material. - 1 § $77.64 \mathrm{~mm}, 1$ $79.40 \mathrm{~mm}$; Ayer Is1.; sand and coral rubble; coll. M. K. Moosa, 26/2/1972; cat. no. S. 1209 -1210.

Previous record. - None. A new record for the area.

\section{Pseudosquilla oculata (BRULLE 1836)}

Pseudosquilla oculata Kemp 1913: 102 -103. - Holthuis 1941: 266 - 267. — MANNing \& SERENE 1968: 115 (listed).

Material. - 1 ઈ 38.24 mm; Panjang Isl., Sunda Strait; coll. Kasijan R., 16/3/1963; cat. no. S. 356.

Remarks. - Additional description of several characters: Cornea is markedly broader than eyestalk. Rostral plate armed with a sharp anterior spine. Carapace with a pair of dark spot surrounded by an entire white ring. Dorsal surface of telson with 4 pairs of carinae on either side of median carina.

Previous record. - None. A new record for the area.

\section{LYSIOSQUILLIDAE GIESBRECHT 1910}

\section{Acanthosquilla derijardi MANNING 1969}

Acanthosquilla deryardi MANNING 1969 C: 1434-1438, fig. 2. - Moosa 1973: 13-14.

Material. - 1 q $30.80 \mathrm{~mm}$; Jakarta Bay, 0551'35"S., 10609'40"E.; dredged, 30-35 M; muddy sand; coll. R.V. SAMUDERA, 5/5/1971; cat. no. S. 463.

Previous record. - None. A new record for the area.

\section{Lysiosquilla maculata (FABRICIUS 1793)}

Squilla maculata FABRICIUS 1793: 511.

Lysiosquilla maculata KeMP 1913: 111-116, pi. 8, figs. 86-91. - SUNIER 1918:

11, fig. 4. - Holthuis 1941: 269-272, fig. 5. - MAnning \& Serene 1968:

116 (listed). 
Material. - $1 \uparrow 204.80 \mathrm{~mm}$; east of Untung Jawa Isl.; coll. M. K. Moosa, 30/12/1963; cat. no. S. 001. - 1 ○े $223.48 \mathrm{~mm}$; data as above; cat. no. S. 002. - 2 ○े $ठ 158.90-242.18 \mathrm{~mm}$ right raptorial claw missing; Jakarta Bay; coll. Verwey, 1929; cat. no. S. 009-010. - 1 o $214.58 \mathrm{~mm}$; data

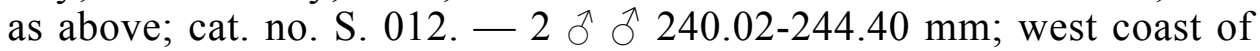
Rengit Is1.; coll. Kasijan R., 23/2/1961; cat. no. A. 013-014. - 1 त $278.04 \mathrm{~mm}$; south coast of Pancalirang Timur Isl.; coll. Kasijan R., 24/2/1961; cat. no. S. 015. - 1 o 253.16 mm; 2 ㅇ q 187.84 -195.72 mm; west coast of Rengit Isl.; coll. Kasijan R., 23/2/1961; cat. no. S. 016 - 018. - 1 ð 226.00 mm; Kongsi Is1.; coll. Sapri D., 27/7/1972; cat. no. S. 871.

Previous records. - Panggang Island; Ancol (SUNIER 1918), Jakarta Bay (SUNIER 1918, HolTHUIS 1941).

\section{SQUILLIDAE LATREILLE 1804}

\section{Alima hyalina LEACH 1817}

Alima hyalina MANNING 1969 b: 128-135, figs. 37, 38, 39 a. - 1969 c: 89-90, fig. I.

Material. - 1 + 42.24 mm; Kongsi Isl.; coll. Sukardi, 29/6/1973; cat. no. S. 1194.

Remarks. - The specimen fully agree with the description and figures of MANNING (1969 b). Corneal index 354, the rostrum shows a little eruption on its lateral side.

Previous record. - None. A new record for the area.

\section{Anchisquilla fasciata (DE HAAN 1844)}

Squilla fasciata De HAAN 1844: 224, Tab. LI, fig. 4. - KEMP 1913: 33-36, pi. 1, fig.

21-23. - HANSEN 1926: 5 - 6. - Holthuis 1941: 242-243. - SERENE 1954: 59-60, pi. 3, figs. 1-4.

Anchisquilla fasciata MANNING \& SERENE 1968: 116 (listed). - MoOSA 1973: 17.

Material. - 1 + 60.22 mm; Ayer Isl.; light fishing; coll. Sapri D., 24/5/ 1971; cat. no. S. 474.

Remarks. - MANNING (1968) created the genus Anchisquilla with Squilla fasciata DE HAAN 1844 as the type of the genus. At present this genus consists of 5 species. One of the main generic characters of the genus 
is the presence of movable apices on submedian teeth of telson (not present on Squilla fasciata but present on all the other known members of the genus). MANNING (1968) stated that Anchisquilla consisted of species with diversified characters. Further study may reveal that this species will have to be separated from the other members of this genus. The characters that they share in common are the presence of movable apices on the submedian teeth of telson and the presence of the four epipods. By the complete absence of the movable apices of the submedian teeth of telson, it is clearly indicated that Anchisquilla fasciata is separated from the remaining species of Anchisquilla for which MANNING (personal communication) agrees that the remaining species of Anchisquilla may need a new generic name. Following MANNING'S key for the genera of Squillidae (MANNING 1968) Squilla fasciata will come into either Squilla or Squilloides. By having reduced complement of dorsal carinae on carapace and less developed abdominal carination, Squilla fasciata is much closer to Squilloides than to Squilla, which is unfortunately regarded as Atlanto-East Pacific genus. Further study is required to clear up the exact generic position of this species.

Previous record. - None. A new record for the area.

\section{Carinosquilla lirata (KEMP \& CHOPRA 1921)}

Squilla lirata KeMP \& CHOPRA 1921: 303-307, figs. 3, 4. - TweEdIE 1934: 39-40. Carinosquilla lirata MANNING \& SERENE 1968: 116 (listed).

Material. - la $50.74 \mathrm{~mm}$, raptorial claws missing; Pasar Ikan fish-market; coll. M. K. Moosa, 23/5/1971; cat. no. S. 159.

Previous record. - None. A new record for the area.

\section{Carinosquilla multicarinata (WHITE 1847)}

Squilla multicarinata KeMP 1913: 86-88, pi. 4, figs. 73-76. - SUNIER 1918: 9. Carinosquilla multicarinata MANNING \& SERENE 1968: 116 (listed). MoOSA 1973: 17.

Remarks. - The specimen is not represented in the collection from Seribu Islands and adjacent waters. The species is known only from western Seribu Islands (SUNIER 1918). 


\section{Clorida latreillei EYDOUX \& SOULEYET 1841}

Clorida latreillei Eydoux \& Souleyet 1841: 265 - 266, pi. 5, figs. 2 - 5. - MANNing \& SERENE 1968: 116 (listed).

Chlorodiella latreillei WoOD-MASON 1895: 7 - 8, pi. 4, figs. 6 -13.

Squilla latreillei KEMP 1913: 24-27, pi. 1, figs. 1-4.

Material. - 1 juvenile; Jakarta Bay, 0558'30"S., 106³7'E, dredged, $16 \mathrm{M}$; mud; coll. R.V. SAMUDERA, 4/5/1971; cat. no. S. 464. - 1 $954.82 \mathrm{~mm}$; Ancol, Jakarta; hand-dredged, 7 - $8 \mathrm{M}$; sandy mud; coll. Kasijan R., 9/10/1964; cat. no. S. 508.

Previous record. - None. A new record for the area.

\section{Cloridopsis scorpio (LATREILLE 1825)}

Squilla scorpio LATREILLE 1825: 472. - KEMP 1913: 42-44, pi. 2, fig. 30 . SUNIER 1918: 4. - HOLTHUIS 1941: 243-244.

Cloridopsis scorpio MANNING \& SERENE 1968: 117 (listed).

Material. - 1 + $21.28 \mathrm{~mm}$; west coast of Pasar Ikan river mouth; small beach-seine; mud; coll. M. K. Moosa, 5/8/1972; cat. no. S. 853. - 1 $62.12 \mathrm{~mm}$; Bintang Mas, Jakarta; small beach-seine; mud; coll. M. K. Moosa, 26/8/1972; cat. no. S. 884.

Previous records. - Pasar Ikan fishmarket (SUNIER 1918 as Batavia fishmarket, the specimens probably were collected from Pasar Ikan river mouth or from the neighbouring coast), Tanjung Priok, Jakarta Bay (HolTHUIS 1941).

\section{Harpiosquilla harpax (DE HAAN 1844)}

Squilla harpax DE HAAN 1844: 222, tab. LI, fig. 1. - TIWARI \& BISWAS 1952: 358 -359 , fig. 3.

Squilla raphidea KemP 1913 (partim) : 88 - 92, pi. 7, fig. 77. - HolthUIS 1941 (partim) : 256-257.

Harpiosquilla harpax MANNING \& SERENE 1968: 117 (listed). - MANNING 1969 d: 25-33, figs. 28-38.

Material. - 1 \& $176.56 \mathrm{~mm}$, left eye and left raptorial claw missing; Jakarta Bay; coll. W. C. van Heurn, May 1927; cat. no. S. 133. - 1 ते 115.86 mm; Jakarta Bay; coll. Kasijan R., 15/7/1961; cat. no. S. 217. - 3

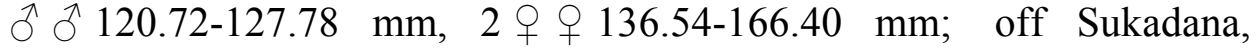


east of Lampung, South Sumatera; coll. Nurzali, 5/1/1973; cat. no. S. $1202-1207$.

Previous records. - Uncertain. Probably some specimens mentioned by SUNIER (1918) and HoLTHUIS (1941) as raphidea were harpax.

\section{Harpiosquilla raphidea (FABRICIUS 1798)}

Squilla raphidea FABRICIUS 1798: 416. — KEMP 1913 (partim): 88 - 92, pi. 7, fig. 77. SUNIER 1918: 9-10, fig. 3. - HOLthuis 1941 (partim): 256-257. — TIWARI \& BiSWAS 1952: 356-358, fig. 3.

Harpiosquilla raphidea MANNING \& SERENE 1968: 117 (listed). — MANNING 1969 d: 9-15, figs. 4-9.

Material. - 1 + 122.96 mm; Jakarta Bay; coll. W. C. van Heurn, May 1927; cat. no. S. 134. - 1 क 237.92 mm; Aquarium Pasar Ikan (collected from Jakarta Bay?); coll. M. K. Moosa, 19/11/1963; cat. no. S. 147.

Remarks. - A large specimen from Aquarium Pasar Ikan is seriously damaged. Right basal prolongation of uropod shows abnormality in form of the spine, outer smaller spine bifurcates to subequally large spines, making the basal prolongation as though bearing 3 spines.

Previous records. - Since the materials mentioned by SUNIER (1918) and HoLTHUIS (1941) probably consisted of both raphidea and harpax. the distribution is uncertain. The specimens of SUNIER from Jakarta were probably harpax, judging from their smaller sizes with the largest of $16.5 \mathrm{~cm}$ in length. Figure 3 of SUNIER is undoubtedly raphidea which was collected from Bagan Siapiapi, east Sumatera. The specimens of HoLTHUIS from Tanjung Priok and from Jakarta Bay were probably true raphidea, judging from their larger sizes.

\section{Oratosquilla gonypetes (KEMP 1911)}

Squilla gonypetes KEMP 1911: 96-97. - 1913: 54-55, pi. 4, figs. 42-44. SUNIER 1918: 5-6. - HANSEN 1926: 10. Oratosquilla gonypetes MANNING \& SERENE 1968: 117 (listed). MoOSA 1973: 24.

Remarks. - This species is not represented in the collection, and known only from west of Seribu Islands (SUNIER 1918). 


\section{Oratosquilla holochista (KEMP 1911)}

Squilla holochista KEMP 1911: 97-98. - 1913: 64-65, pi. 4, figs. 50-53. SUNIER 1918: 8. - HOLTHUIS 1941: 246-247.

Oratosquilla holochista MANNING \& SERENE 1968: 117 (listed). MANNING 1971: 3 (in key).

Remarks. - This species is not represented in the collection, and known only from Anyer, Sunda Strait (SUNIER 1918).

\section{Oratosquilla inornata (TATE 1883)}

Squilla oratoria var. perpensa KEMP 1913 (partim): 70-72. — SUNIER 1918: 8. Squilla oratoria var. inornata HOLTHUIS 1941: 248-249.

Squilla inornata MANNING 1966: 95-97, fig. 3.

Oratosquilla inornata MANNING \& SERENE 1968: 117 (listed) misprint as Oratosquilla ornata TATE 1883. - MANNING 1971: 8 (in key).

Material. - 1 q $62.98 \mathrm{~mm}$, Pasar Ikan fish market; coll. M. K. Moosa, 22/5/1971; cat. no. S. 161. - 1 त $38.76 \mathrm{~mm}$; west coast of Pasar Ikan river mouth; coll. M. K. Moosa, 5/8/1972; cat. no. S. 851.

Previous record. - None. A new record for the area.

\section{Oratosquilla interrrupta (KEMP 1911)}

Squilla interrrupta KeMP 1911: 98-99. - 1913: 72-74, pi. 5, figs. 60-62. SUNIER 1918: 8. - HANSEN 1926: 11. - Holthuis 1941: 253-254. MANNING 1966: 97-98, fig. 4.

Oratosquilla interrupta MANNING \& SERENE 1968: 117 (listed). — MANNING 1971: 8 (in key).

Material. - $1993.22 \mathrm{~mm}$; Jakarta; in poor condition; MZB cat. no. Cru. 210.

Previous records. - West of Seribu Islands (SUNIER 1918), Jakarta Bay (HOLTHUIS 1941).

Oratosquilla jakartensis new species

(Figs. 1 a, b, c and d)

Material. - Holotype: 1 † $54.24 \mathrm{~mm}$; Pasar Ikan fish market; coll. M. K. Moosa, 22/5/1971; cat. no. S. 160. — Paratype: 1 त 39.58 mm; data as holotype; coll. M. K. Moosa, 12/6/1971; cat. no. S. 162. 
Description. - Dorsal surface of body smooth, glabrous. Eyes large, with bilobed cornea, set very obliquely on stalk; eyes not extending beyond end of first segment of antennular peduncle; ocular scale truncate, widely separated; anterior end of ophthalmic somite with a small triangular median notch; C I 308 in male and 313 in female. Antennular somite blunt. Antennal scale slender, short, more than half as long as carapace. Carapace broad, anterior width more than half median length (including rostrum); anterolateral spines sharp, size moderate, not extending to base of rostral plate; median carina of carapace obscure anteriorly, anterior bifurcation replaced by lines of dark pigment. Dactylus of raptiorial claw with 6 teeth; outer margin of dectylus sinuate; dorsal ridge of carpus tuberculate, with 2 tubercles at distal end of sharp median ridge; inferodistal angle of outer face of merus with blunt, triangular notch. Mandibular palp and four epipods present. Last three of thoracic somites with submedian carinae; fifth somite faint; indication of submedian carina on posterior half; lateral process of fifth somite bilobed, with anterior lobe as an anteriorly directed blunt spine and posterior lobe slender, sharp, directed laterally; lateral process of sixth somite bilobed, with anterior lobe slightly recurved posteriorly and posterior lobe larger and triangular in shape; lateral process of seventh somite bilobed, with anterior lobe small, triangular with blunt apex and posterior lobe much larger with acute apex; ventral keel of eight somite low, rounded. First five abdominal somites with eight dorsal carinae; submedians parallel on four anterior somites, divergent on fifth; abdominal carinae equipped with spines arranged as follows: submedian 5-6, intermediate 3-6, lateral 2-6, marginal 1 - 5; sixth somite with a small ventrolateral spine in front of articulation of each uropod. Telson somewhat broader than long, armed with six slender marginal teeth; praelateral lobe present; dorsal surface ornamented with one median carina and carinae of marginal teeth, supplementary dorsal tubercles absent; denticles rounded, arranged as 3 - 4 submedian, 9 intermediate, 1 lateral; ventral surface with an entire post-anal keel. Outer margin of uropodal exopod with eight movable spines, with largest distalmost not reaching midlength of distal segment; endopod slender, slightly curved; basal prolongation of uropod with sharp triangular projection on outer margin of inner longer spine, inner margin of projecting lobe concave (Fig. Id).

Other measurements. - Holotype: TL $54.24 \mathrm{~mm}$; CI $10.80 \mathrm{~mm}$; cornea width $3.44 \mathrm{~mm}$; anterior carapace width $6.34 \mathrm{~mm}$. 


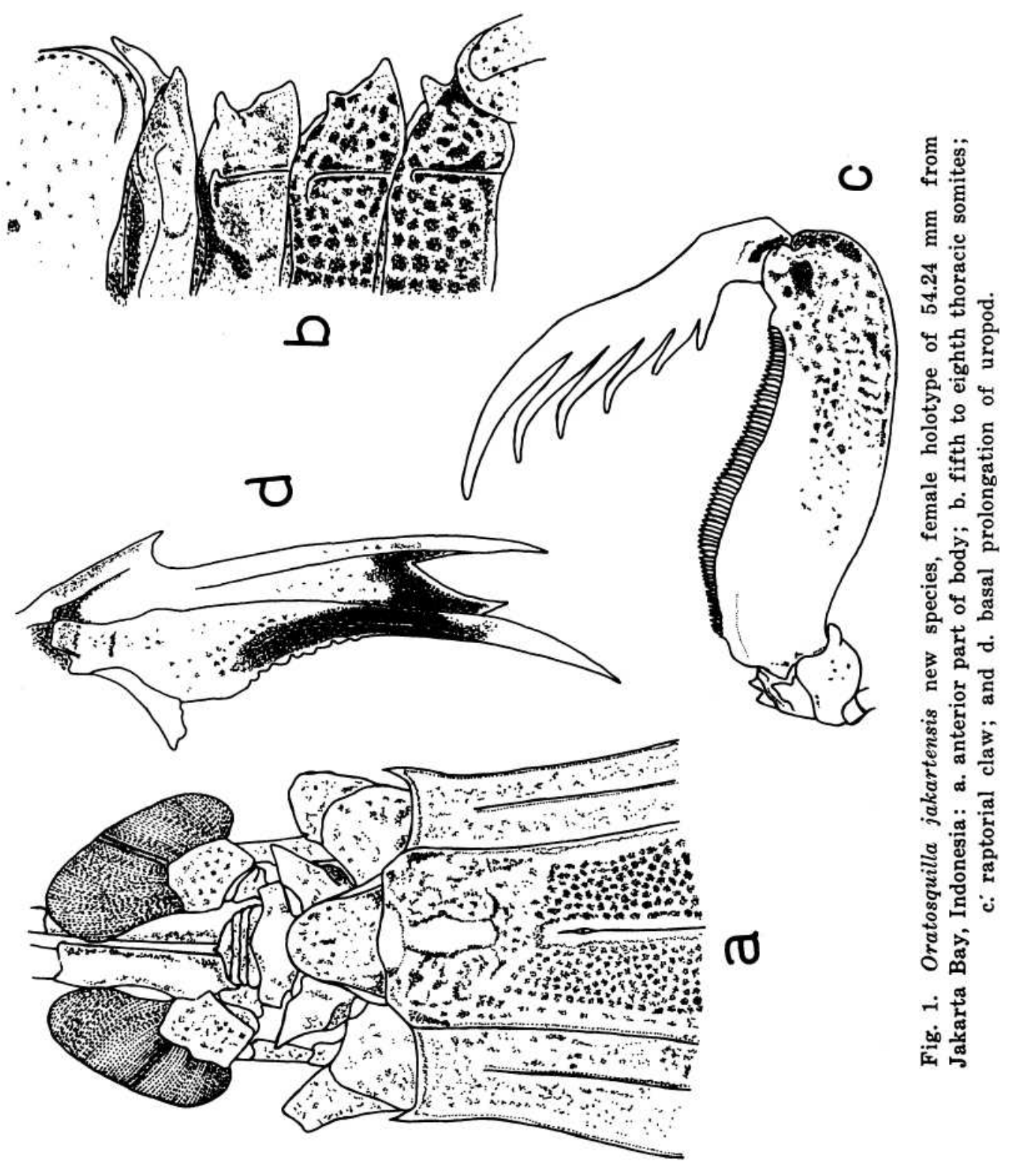


Paratype: TL $39.58 \mathrm{~mm}$; CI $7.90 \mathrm{~mm}$; cornea width $2.56 \mathrm{~mm}$; anterior carapace width $4.56 \mathrm{~mm}$.

Colour. - The preserved specimens are greyish mottled heavily with dark pigment. Median dorsal surface of the carapace, median dorsal surface of the exposed thoracic somites, median posterior margin of the first five abdominal somites, posterolateral portion of the sixth abdominal somite, outer distal part of the raptorial propodus, distal portion of the uropodal endopod and dorsolateral portion of the telson are the more heavily pigmented areas. Black pigmentation can be seen on the distal part of proximal segment of uropodal exopod, the midrib of distal segment of the uropodal exopod (on which the pigmentation becomes less toward inner margin), the inner and distal margin of the basal prolongation of the uropod, and the carinae of the marginal teeth of telson.

Remarks. - Oratosquilla jakartensis clearly belongs to the woodmasoni group, which is characterized by the broad, smooth carapace and the absence of anterior bifurcation of median carina.

$O$. jakartensis very closely resembles $O$. woodmasoni and $O$. tweediei. From $O$. woodmasoni it can be distinguished by the more prominent anterior lobe of the lateral process of the sixth and seventh thoracic somites and the much more prominent lobe on the outer margin of the inner longer spine of the basal prolongation of the uropod. From $O$. tweediei it is distinguished by the unarmed posterior submedian carina of the fourth abdominal somite and a median notch present at anterior margin of the ophthalmic somite of jakartensis (rounded in tweediei).

CHOPRA (1934) mentioned a single female of $80 \mathrm{~mm}$ from Sandheads, India, together with some specimens from various localities in the Indian Museum collection as showing the presence of a small notch on anterior margin of the ophthalmic somite and the more developed lobe at the outer margin of the inner longer spine of the basal prolongation of the uropod.

These characters were also mentioned by HoLTHUIS (1941) in the Snellius specimens which were partly collected from Jakarta. Some of the Snellius specimens and those mentioned by CHOPRA may belong to jakartensis. This supposition is supported by the fact that both authors did not mentioned the presence of the armed submedian carina of the fourth abdominal somite.

Type locality. — Jakarta Bay, Indonesia. 
Etymology. - The specific name is derived from the type locality, the Jakarta Bay.

\section{Oratosquilla nepa (LATREILLE 1825)}

Squilla nepa LATREILle 1825: 471 - 472. - KeMP 1913: 60 - 64, pi. 4, fig. 49. SUNIER 1918: 6-7, fig. 2. — HANSEN 1926: 10-11. — HOLTHUIS 1941: 245-246. Oratosquilla nepa MANNING \& SERENE 1968: 117 (listed). — MANNING 1971: 3 (in key).

Material. - $1 \uparrow 105.28 \mathrm{~mm}$; Pasar Ikan fishmarket, Jakarta; coll. M. K. Moosa, 1/2/1965; cat. no. S. 042. - 1 q $113.82 \mathrm{~mm}$; Pasar Ikan fishmarket, Jakarta; coll. M. K. Moosa, 3/11/1965; cat. no. S. 075. - 1 † 137.58 mm; Undrus Isl., Jakarta Bay; coll. Kasijan R., 9/1/1962; cat. no. S. 123. - 2 우 우 116.22-125.80 mm; water reservoir, Pluit Project, Jakarta; cast net; coll. Saniman, 21/12/1964; cat. no. S. 124-125. - 4 O q $80.74-146.06 \mathrm{~mm}$; fish pond, Muara Baru, Jakarta; cast net; coll. Saniman, 10/12/1964; cat. no. S. $126-130$ - 1 ㅇ 132.48 mm; Pasar Ikan fishmarket, Jakarta; coll. Sapri D., 1/11/1965; cat. no. S. 171. - 1 q $113.80 \mathrm{~mm}$; Sakit Isl., Jakarta Bay; coll. Kasijan R., 28/6/1962; cat. no. S. $181 .-1$ § $86.82 \mathrm{~mm}$; Petundang Isl.; coll. Kasijan R., 8/8/1961; cat. no. S. 292. - 1 o 105.86 mm; Sakit Isl., Jakarta Bay; coll. Kasijan R., 28/6/1962; cat. no. S. 293. - 1 q 111.42 mm; water reservoir, Pluit Project, Jakarta; coll. Sudarmo, 15/2/1966; cat. no. S. 305. - 1 o $45.50 \mathrm{~mm}, 1$ + $83.72 \mathrm{~mm}$; Muara Karang fishmarket, Jakarta; coll. Sularto M., 20/8/1971; cat. no. S. 330 - 331. - 1 q 92.38 mm; West coast of Muara Karang river mouth; cast net; coll. M. K. Moosa et al, 15/7/1972; cat. no. S. 852. — 9 ô ते 68.02 - 84.94 mm, 7 q $q 49.62$ $94.42 \mathrm{~mm}$; West coast of Pasar Ikan river mouth, Jakarta; cast net; mud; coll. M. K. Moosa et al 5/8/1972,; cat. no. S. 854-863. - 1 ○ 69.96 mm; Muara Kalong, Jakarta; mud; coll. M. K. Moosa et al, 19/8/1972; cat. no. S. 1200. - 1 त $115.84 \mathrm{~mm}$; off Sukadana, east of Lampung, South Sumatera; coll. Nurzali, 3/1/1973; cat. no. S. 1201.

Previous records. - Jakarta; Jakarta fishmarket; Muara Baru; east of Pasar Ikan river mouth; Ancol; Damar Kecil Island; near Tanjung Priok (SUNIER 1918; HolTHUIS 1941).

\section{Oratosquilla quinquedentata (BROOKS 1886)}

Squilla quinquedentata BROOKS 1886: 26-30, pi. 1, fig. 3, pi. 2, fig. 6. - KEMP 1913: 52-53. — SUNIER 1918: 5. — HOLTHUIS 1941: 244-245. 
Oratosquilla quinquedentata MANNING \& SERENE 1968: 177 (listed). — MANNING 1971: 14 (in key).

Remarks. - The species is not represented in the collection, and known only from northwest of Seribu Islands (SUNIER 1918).

Oratosquilla tweediei MANNING 1971

Oratosquilla tweediei MANNING 1971: 12 -14, fig. 4.

Material. - 1 q 95.98 mm; Jakarta Bay; cat. no. S. 205. - 1 i 115.48 $\mathrm{mm}$; off Sukadana, east of Lampung, South Sumatera; coll. Nurzali, 5/1/1973; cat.no. S. 1208.

Remarks. - The specimens fully agree with the description and figure of MANNING (1971). The spines of the lateral, intermediate and sub-median carinae of the last two abdominal somite are pink in colour. The spine on the dorsal surface of the proximal segment of the uropod is also pink. The marginal teeth of the telson are olive green.

Previous record. - None. A new record for the area.

\section{Oratosquilla woodmasoni (KEMP 1911)}

Squilla woodmasoni KeMP 1911: 99. - 1913: 74-76, pi. 5, figs. 63-65. - SUNIER 1918: 9. - Hansen 1926: 12. - Holthuis 1941: 255. - Manning 1966: 100 -101, fig. 5.

Oratosquilla woodmasoni MANNING \& SERENE 1968: 117 (listed). — MANNING 1971: 11 (in key).

Remarks. - The species is not represented in the collection, and known only from northwest of Seribu Islands (SUNIER 1918), Tg. Priok, Jakarta (HolTHUIS 1941).

\section{ACKNOWLEDGEMENTS}

The author would like to thank Messrs. NuRZALI NAAMIN, Lembaga Penelitian Perikanan Laut (LPPL = Institute of Sea Fisheries Research), and SuTIKNO, Museum Zoologi Bogor (= Museum Zoologicum Bogoriense), for their kind cooperation in supplying the material for the study. I am greatly indebted to Dr. R. B. MANNING of the Smithsonian Institution for his comments, advices and help in supplying literatures. 


\section{REFERENCES}

BroOKS, W. K. 1886. The Stomatopoda collected by H.M.S. "CHALLENGER" Rep. Sci. Res. "CHALLENGER", zool. 16: 1-116, 1-16.

CHOPRA, B. 1934. On the stomatopod Crustacea collected by the R. Pilot Service off the mouth of the River Hughly, together with some notes on other forms. Rec. Indian Mus. 36: 17-43, 5 figs.

De HaAn, W. 1833-1850. Crustacea. In: P.F. De Siebold, Fauna Japonica sive descriptio animalium, quae in itinere per Japoniam, jussu et auspicis superiorum, qui summum in India Batavia Imperium tenent, suscepto, anniis 1823 -1830 collegit, notis, observationibus et adumbrationibus illustravit, I -XVI, I-XXXI, VII-XVII, 1-243, 72 pls. circ. 2. A. Arnz. Lugduni Batavorum.

De Man, J. G. 1887. Bericht uber die von Herrn Dr. G. Brooks im Indischen Archipel gesammelten. Dekapoden und Stomatopoden. Arch. Natuurgesch. 53(1): 571-583.

Eydoux, A. M. and L. Souleyet 1841. Vojage autour du monde, execute par M. Vaillant sur la corvette "LA BONITE", Zool., 1, Crustacea: 262-266, 1 pi.

FABRICIUS, J. C. 1781. Species insectorum exhibentes eorum differentias specif icas, synonyma autorum, loca natalia, metamorphosin adjectis observationibus, descriptionibus; 1: VIII + 552. Carol. Ernest Bohnii, Hamburgi et Kolonii.

-------- 1787. Mantissa insectorum sistens corum species nuper detectas adjectis characteribus genericis, differentiis specificis, emendationibus, observationibus. 1: $\mathrm{XX}+348$. Christ. Gottl. Proft. Hafniae.

-------- 1793. Entomologica systematica. II: 511-573. Hafniae.

1798. Entoviologicae systematicae. Supplementum. Proft et Storch, Hafniae.

Hansen, H. J. 1926. The Stomatopoda of the Siboga Expedition. Siboga Exped. Monogr. 35: 1-48, 2 pls.

Henderson, J. R. 1893. A contribution to Indian Carcinology. Trans. Linn. Soc. London (2), 5: 325-458, 5 pls.

Holthuis, L. B. 1941. Biological results of the Snellius Expedition XII. Stomatopoda of the Snellius Expedition. Temminckia 6: 241-295, 9 figs.

KEMP, S. W. 1911. Preliminary descriptions of new species and varieties of Crustacea Stomatopoda in the Indian Museum. Rec. Indian Mus. 6: 93 -100.

-------- 1913. An account of the Crustacea Stomatopoda of the Indo-Pacific region based on the collection in the Indian Museum. Mem. Indian Mus. 4(1): 1 - 217, 10 pls., 10 text-figs.

-------- and B. CHOPRA 1921. Notes on Stomatopoda. Rec. Indian Mus. 22: 297-311.

Latreille, M. 1825. Squille, Squilla. Encyclopedie Methodique, Hist. Natr. Paris 10: 467-475, 3 pls.

Manning, R. B. 1966. Notes on some Australian and New Zealand stomatopod Crustacea, with an account of the species collected by the fisheries ship "ENDEAVOUR". Rec. Australian Mus. 27(4): 79-137, 10 figs. 
1967. Riview of the genus Odontodactylus (Crustacea: Stomatopoda). Proc. U.S. Nat. Mus. 123 (3606): 1-35, 8 figs.

------- 1968. A revision of the family Squillidae (Crustacea, Stomatopoda), with the description of eight new genera. Bull. Mar. Sci. 18 (1) : 105-142.

1969 a. Notes on the Gonodactylus section of the family Gonodactylidae (Crustacea, Stomatopoda), with descriptions of four new genera and a new species. Proc. Biol. Soc. Washington 82: 143-166, 8 figs.

------- 1969 b. Stomatopod Crustacea of the western Atlantic. Stud Tropical Oceanogr. 8: VII + 380, 91 figs.

1969 c. Some stomatopod crustaceans from Tulear, Madagascar. Bull. Mus. Nat. Hist. Natr. ser. (2), 41(6): 1429-1441, 3 figs.

1969 d. A review of the genus Harpiosquilla (Crustacea, Stomatopoda), with descriptions of three new species. Smithsonian Contr. Zool. 36:1 - 41, 43 figs.

1971. Keys to the species of Oratosquilla (Crustacea, Stomatopoda), with description of two new species. Smithsonian Contr. Zool. 71: 1-116, 4 figs.

and R. SERENE 1968. Prodromus for a checklist of the non-planctonic marine fauna of South East Asia. Stomatopoda. Singapore Nat. Acad. Sci. spec. publ. 1: 113-118.

MOOSA, M. K. 1973. The stomatopod Crustacea collected by the Mariel King Memorial Expedition in Maluku waters in 1970. Mar. Res. Indonesia 13: 1-30, 4 figs.

Pocock, R. J. 1893. Report upon the stomatopod crustaceans obtained by P.W. Basset-Smith Esq., surgeon R.N., during the cruise, in the Australian and China Sea, of H.M.S. "PENGUIN", commander W.U. Moore. Ann. Mag. Nat. Hist. ser. (6), 11: 473-479, $1 \mathrm{pl}$.

SERENE, R. 1947. Sur des stomatopodes rares trouves en Indochina et $n$ 'existant pas dans les collection du Museum. Bull. Mus. Hist. Natr. ser. (2), 19(5): $381-389,4$ pls.

-------- 1954. Observations biologiques sur les stomatopodes. Mem. Inst. Oceanogr. Nhatrang 8: 1-93, 15 figs., 10 pls.

SUNIER, A. L. J. 1918. The Stomatopoda of the collection of the Visschery Station at Batavia. Contr. Faune Indes Neerlandaises 1(4): 62-75, 4 figs.

TiRmizi, N. M. and R. B. MANNING 1968. Stomatopod Crustacea from West Pakistan. Proc. U.S. Nat. Mus. 125 (36666): 1-48, 17 figs.

TIWARI, K. K. and S. BISWAS 1952. On two new species of the genus Squilla FABR., with notes on other stomatopods in the collections of the Zoological Survey of India. Rec. Indian Mus. 49(3-4): 349-363, 5 figs.

TweEdIE, M. W. F. 1934. Notes on the Stomatopoda in the Raffles Museum. Bull. Raffles Mus. Singapore 9: 31-41.

Wood-Mason, J. 1875. On new or little known Crustacea. Proc. Asiatic Soc. Bengal: $230-232$.

-------, 1895. Figures and descriptions of nine species of Squillidae from the collection of Indian Museum. Indian Museum, Calcutta: 1-11, 4 pls. 